\title{
Synthesis, Spectral Characterization, Magnetic Moment, Mass, X-Ray Diffraction, and Kinetic (TGA) Studies of Cr(III) Complex with Metformin: An Oral Antidiabetic Drug
}

\author{
Bal Krishan' ${ }^{1}$ and S. A. Iqbal ${ }^{2}$ \\ ${ }^{1}$ Department of Chemistry, Saifia Science College, Barkatullah University, Bhopal 462001, India \\ ${ }^{2}$ Department of Chemistry, Crescent College of Technology, Nabi Bagh, Karond, Bhopal 462038, India \\ Correspondence should be addressed to Bal Krishan; bkrishan.krg@gmail.com
}

Received 11 May 2013; Accepted 16 December 2013; Published 18 February 2014

Academic Editor: Tanaji Talele

Copyright (c) 2014 B. Krishan and S. A. Iqbal. This is an open access article distributed under the Creative Commons Attribution License, which permits unrestricted use, distribution, and reproduction in any medium, provided the original work is properly cited.

\begin{abstract}
The present work describes synthesis, spectral characterization, and X-ray diffraction studies of Cr(III) with "metformin," an oral antidiabetic drug. The conductometric titration using monovariation method indicates that complex is ionic and of $\mathrm{L}_{2} \mathrm{M}$ type. Analytical data agree with the molecular formula of complex namely, $\left[\left(\mathrm{C}_{4} \mathrm{H}_{11} \mathrm{~N}_{5}\right)_{2} \mathrm{Cr}\left(\mathrm{H}_{2} \mathrm{O}\right)_{2}\right] 2 \mathrm{Cl}$. Geometry of complex assigned is octahedral, supported by IR, electronic spectra, magnetic moments, ${ }^{1} \mathrm{H}-\mathrm{NMR}$ and mass studies, and proposed structure (I) for complex. X-ray diffraction data also supports the complex formation and symmetry of complex and various parameters like particle size, porosity, volume of unit cell, and density have been calculated. The Freeman-Carroll and Sharp-Wentworth methods have been used to calculate activation energy and thermal stability. The activation energy $\left(E_{a}\right)$ calculated with the help of these methods are in agreement with each other. Thermodynamic parameters such as free energy change $(\Delta F)$ and entropy change are also determined on the basis of TG curves and by using data of the Freeman-Carroll method.
\end{abstract}

\section{Introduction}

Metal ions are required for many critical functions in humans. Scarcity of some metal ions can leads to disease [1]. Well-known example are pernicious anemia resulting from iron deficiency; growth retardation arising from insufficient dietary of zinc and heart disease in infants due to copper deficiency. The ability to recognize and to understand at the molecular level and the diseases caused by inadequate metalion function constitutes an important aspect of medicinal bioinorganic chemistry. Understanding the biochemistry and molecular biology of natural detoxification mechanisms and designing and applying ion-specific chelating agents to treat metal overloads are two components of a second major aspect of the new science that is evolving at the interface of bioinorganic chemistry and medicine.

Diabetes is a deceptive disease and if not detected in early stage may cause even death. It is considered hereditary but actual genetic disorder is still a mystery. Several million people are suffering from this disease all over the world which is reported by Sadilot and Phatak [2], Bloomgarden [3], and Sanger and Thompson [4]. Zinc-insulin was discovered as early as in 1921 and later it proved to be a very efficacious medicine in the treatment of diabetes mellitus. To avoid the daily pricks of hypodermic syringe, oral hypoglycemic agents were discovered, which has revolutionized the treatment of diabetes. It is worthwhile to mention here that the majority of the essential metallic elements of biological importance are transition metals, whose ability to form coordination complexes and a chelate is the characteristic aspects of their chemistry.

In recent years much attention is given to the use of sulphonylurea because of their high complexing nature with essential metals. Sulphonylurea are effective for noninsulin dependent diabetes mellitus, reported by Sadilot and Phatak [2], Bloomgarden [3], and Sanger and Thompson [4]. These 
<smiles>CN(C)C(=N)NC(=N)[NH2+]Cl</smiles>

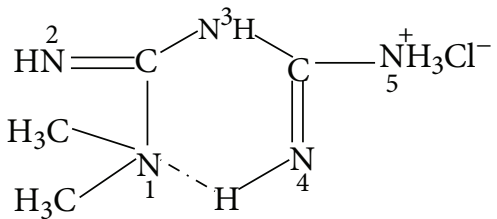

Or

SCHEME 1: Structure of Metformin.

compounds are completely absorbed by oral administration. They are metabolized by liver and are excreted predominantly through urine.

Complexation of sulphonylurea with lighter transition metals has been studied in detail by Yoshinaga and Yamamotto $[5,6]$ and complexation of sulphonylurea and biguanidine by Iqbal et al. [7] and others [8].

Metformin is sold under several trade names, including Glucophage XR, Riomet, Fortamet, Glumetza, obimed, Gludormin, Diarber, Diaber, and Diaformin. Broad interest in metformin was not rekindled until the withdrawal of the other biguanides in the 1970s. Generic formulations are now available in several countries and metformin is believed to have become the most widely prescribed antidiabetic drug in the world; therefore looking the importance of metformin, we have studied metformin complex with chromium (see Scheme 1).

\section{Experimental}

\subsection{Ligand-Metal Ratio}

(a) Pure "Metformin" 0.828 gram $(0.005 \mathrm{M})$ was dissolved in $100 \mathrm{~mL}$ of ethanol and 0.66 gram $(0.01 \mathrm{M})$ chromium chloride in $100 \mathrm{~mL}$ ethanol. $10 \mathrm{~mL}$ metformin solution was diluted to $100 \mathrm{~mL}$ in a beaker. This was titrated conductometrically against chromium chloride solution taken in burette using fractions of $1 \mathrm{~mL}$. Conductance was recorded after each addition with proper stirring at temperature $30 \pm$ $1^{\circ} \mathrm{C}$. Results were plotted in the form of a graph between corrected conductance and volume of metal salt. From the equivalent point in the graph, ratio between metal and ligand was noted to be $1: 2$.

(b) Formation of 2:1 ( $\left.\mathrm{L}_{2} \mathrm{M}\right)$ ratio was also confirmed by Job's method [9] of continuous variation as modified by Turner and Anderson [10] (Table 1 and Figures 1(a) and 1(b)) using absorbance as index property; from these values the stability constant $(\log k)$ and free energy change $(-\Delta F)$ were also calculated by using formula $k=x /\left(\left(a_{1}-x\right)\left(b_{1}-2 x\right)^{2}\right)=x /\left(\left(a_{2}-\right.\right.$ $\left.x)\left(b_{2}-2 x\right)^{2}\right)$, where $k=$ Stability constant, $x=$ Conc. of complex, and $\Delta G=-R T \ln k$, respectively.

2.2. Synthesis of Complex. The chemicals used in this synthesis were all of analytical grade E-Merck. A weighed
TABLE 1: Metformin with chromium chloride.

\begin{tabular}{lccccc}
\hline \multirow{2}{*}{ S. number Metal : ligand } & \multicolumn{2}{c}{ Absorbance } & \multicolumn{3}{c}{ Corrected absorbance } \\
& & $.002 \mathrm{M}$ & $.005 \mathrm{M}$ & $.002 \mathrm{M}$ & $.005 \mathrm{M}$ \\
\hline 1 & $0: 12$ & 0.008 & 0.005 & 0.00 & 0.00 \\
2 & $1: 11$ & 0.016 & 0.018 & 0.008 & 0.013 \\
3 & $2: 10$ & 0.024 & 0.029 & 0.016 & 0.023 \\
4 & $3: 9$ & 0.039 & 0.046 & 0.031 & 0.040 \\
5 & $4: 8$ & 0.052 & 0.062 & 0.044 & 0.056 \\
6 & $5: 7$ & 0.045 & 0.051 & 0.037 & 0.044 \\
7 & $6: 6$ & 0.04 & 0.049 & 0.032 & 0.042 \\
8 & $7: 5$ & 0.029 & 0.042 & 0.021 & 0.035 \\
9 & $8: 4$ & 0.024 & 0.032 & 0.016 & 0.024 \\
10 & $9: 3$ & 0.018 & 0.028 & 0.010 & 0.020 \\
11 & $10: 2$ & 0.015 & 0.025 & 0.008 & 0.017 \\
12 & $11: 1$ & 0.011 & 0.014 & 0.002 & 0.004 \\
13 & $12: 0$ & 0.009 & 0.011 & 0.00 & 0.00 \\
\hline
\end{tabular}

quantity of "Metformin" (2 mol) was dissolved separately in minimum quantity of $90 \%$ ethanol. The chromium solution was prepared by dissolving separately in the same solvent. Ligand solution was added slowly with stirring into the solution of metallic salt at room temperature, maintaining the $\mathrm{pH}$ between 6.0 and 6.5 by adding dilute $\mathrm{NaOH}$ solution. On refluxing the mixture for $3-4 \mathrm{~h}$ and on cooling the complex separated out, which were filtered off, washed well with ethanol, and finally dried in vacuum and weighed.

2.3. Instrumentation. The elemental analysis of the isolated complex was carried out using Coleman Analyzer at the Departmental Microanalytical Laboratory C.D.R.I, Lucknow. Chlorine was determined gravimetrically. Chromium analysis was carried out in Qualichem Laboratory, Nagpur, by atomic absorption spectroscopy (AAS). The IR spectra of the ligand as well as of the complex were recorded on $\mathrm{B}$ OMEM-FTIR, ${ }^{1} \mathrm{H}-\mathrm{NMR}$ spectra of the ligand and isolated complex were recorded on a Bruker AM-200 spectrometer, and $\mathrm{d}_{6}$-DMSO was used as a solvent. IR and ${ }^{1} \mathrm{H}$-NMR spectra were recorded in CDRI Lucknow, India. X-ray diffractometer model Rigaku D-max/B, with $12 \mathrm{~kW}$ Rotating Anode X-ray generator was used for scanning the ligand and respective complex. Anode X-ray generator was used for scanning the ligand and respective complex at SAIF, Punjab University, Chandigarh, India. The radiation used was $\mathrm{Cu}, \mathrm{Ka}(1 \mathrm{~W}$ 


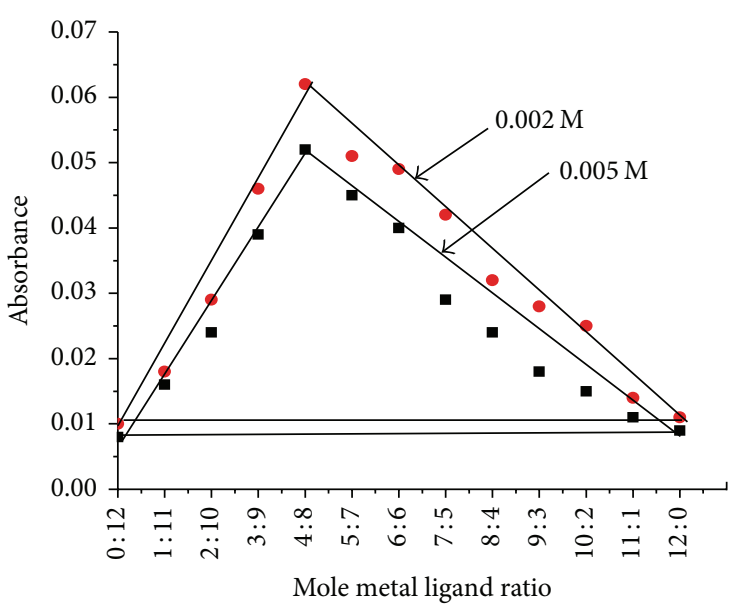

(a)

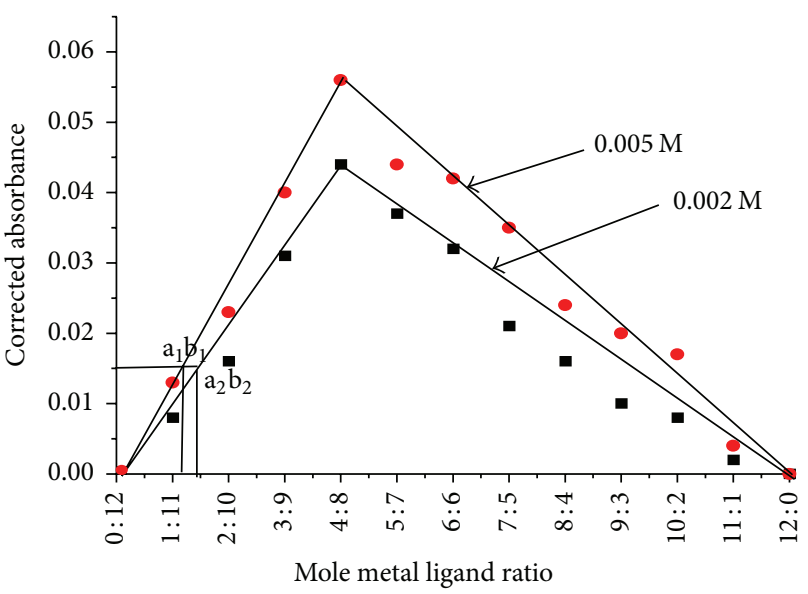

(b)

FIGURE 1: Metformin with chromium chloride.

$=1.5060 \AA)$. The samples were scanned in the range from 10.0084 to $79.9804(2 \theta)$. Powder data were indexes using computer software (FPSUIT V 2.0). TGA spectra were recorded in IIT Bombay, India.

From stoichiometry and analytical data, the composition of the complex comes out to be $\left[\left(\mathrm{C}_{4} \mathrm{H}_{10} \mathrm{~N}_{5}\right)_{2} \mathrm{Cr}\left(\mathrm{OH}_{2}\right)_{2}\right] 2 \mathrm{Cl}$, which favors 2:1 $\left(\mathrm{L}_{2} \mathrm{M}\right)$ ratio. The tentative structure (I) assigned to complex, on the basis of analytical data, was further supported by XRD data. Mass spectra of $\left[\left(\mathrm{C}_{4} \mathrm{H}_{10} \mathrm{~N}_{5}\right)_{2} \mathrm{Cr}\left(\mathrm{OH}_{2}\right)_{2}\right] 2 \mathrm{Cl}$ complex were recorded at C.D.R.I Lucknow, India, which provides information about the complex by examination of the fragmentation pattern and total mass of the complex. Proposed structures (I) for the isolated complex are also supported by mass spectral studies.

\section{Result}

3.1. Physicochemical Characteristics of "Metformin"-Chromium Complex. Molecular formula $\left[\left(\mathrm{C}_{4} \mathrm{H}_{10} \mathrm{~N}_{5}\right)_{2} \cdot \mathrm{Cr}\left(\mathrm{OH}_{2}\right)_{2}\right] 2 \mathrm{Cl}$, Mol. wt: 414.90; colour: green; yield: $56 \%$; m.p: $243^{\circ} \mathrm{C}$, C, 23.02(24.23), H, 5.27(5.60), N, 33.57(30.25), metal, $12.47(11.20), \mathrm{Cl}, 17.02(18.20)$, coordinate water molecule, $8.70(8.30)$, stability constant, 11.035; free energy change $(-\Delta F),-15.28$.

3.2. Electronic Spectral Studies. In Cr(III) complex of "Metformin" the observed magnetic moment is 4.38 and bands observed at $380 \mathrm{~cm}^{-1}$ attributed to charge transfer while the values $350 \mathrm{~cm}^{-1}$ and $295 \mathrm{~cm}^{-1}$ are assignment to the ${ }^{4} \mathrm{~A}_{2 \mathrm{~g}}(\mathrm{~F}) \rightarrow{ }^{4} \mathrm{~T}_{2 \mathrm{~g}}(\mathrm{~F}),{ }^{4} \mathrm{~A}_{2 \mathrm{~g}}(\mathrm{~F}) \rightarrow{ }^{4} \mathrm{~T}_{1 \mathrm{~g}}(\mathrm{~F})$ transition, respectively, suggest a octahedral environment around "Metformin"-chromium complex.

3.3. Magnetic Moments Studies. In the present study, the room temperature of magnetic susceptibility measurement was carried out on a vibration sample magnetometer (VSM) at the Indian Institute of Technology, Roorkee (India). The

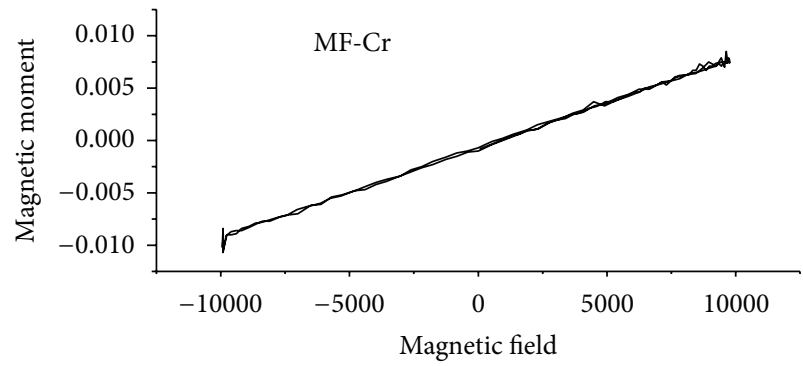

FIGURE 2: Hysteresis curve of "metformin"-chromium complex.

hysteresis curve given in Figure 2 shows the magnetic behavior of complex. The magnetic measurements of complex were carried out on Vibrating Sample Magnetometer (mode 155) which directly gives the $\mu_{\text {eff }}$ values without diamagnetic correction with the help of the following equation:

$$
\mu_{\mathrm{eff}}=2.84 \sqrt{\frac{R T M}{W \cdot H}},
$$

where $R$ is reading of magnetic moment on magnetometer, $T$ is absolute temperature, $M$ is molecular weight of the compound, $W$ is weight of the sample, and $H$ is magnetic field.

Magnetic moment has been calculated and is equal to 4.38 B.M.; moreover hysteresis curve has been shown in Figure 2 that gives the information about magnetism; that is, "metformin"-chromium complex is diamagnetic.

3.4. Infrared Spectral Studies. The IR spectra of ligand and isolated complex (Figure 3) were recorded within the range $4000-400 \mathrm{~cm}^{-1}$. Assignments of the infrared spectral bands are based on literature. IR spectrum shows important bands due to $v(\mathrm{M}-\mathrm{N}) 500 \pm 20 \mathrm{~cm}^{-1}, v(\mathrm{~N}-\mathrm{H}$ wagging in ligand as well as complex) $770 \pm 10 \mathrm{~cm}^{-1}, v(\mathrm{C}-\mathrm{N}-\mathrm{C}) 1215 \pm 10 \mathrm{~cm}^{-1}$, $v(-\mathrm{C}=\mathrm{N}) 1580 \pm 10 \mathrm{~cm}^{-1}$, (amine salt) $2361 \mathrm{~cm}^{-1}, v(\mathrm{C}-\mathrm{H})$ $2910 \pm 20 \mathrm{~cm}^{-1}, \nu\left(\mathrm{NH}_{3}\right.$ frequency in ligand and complex 


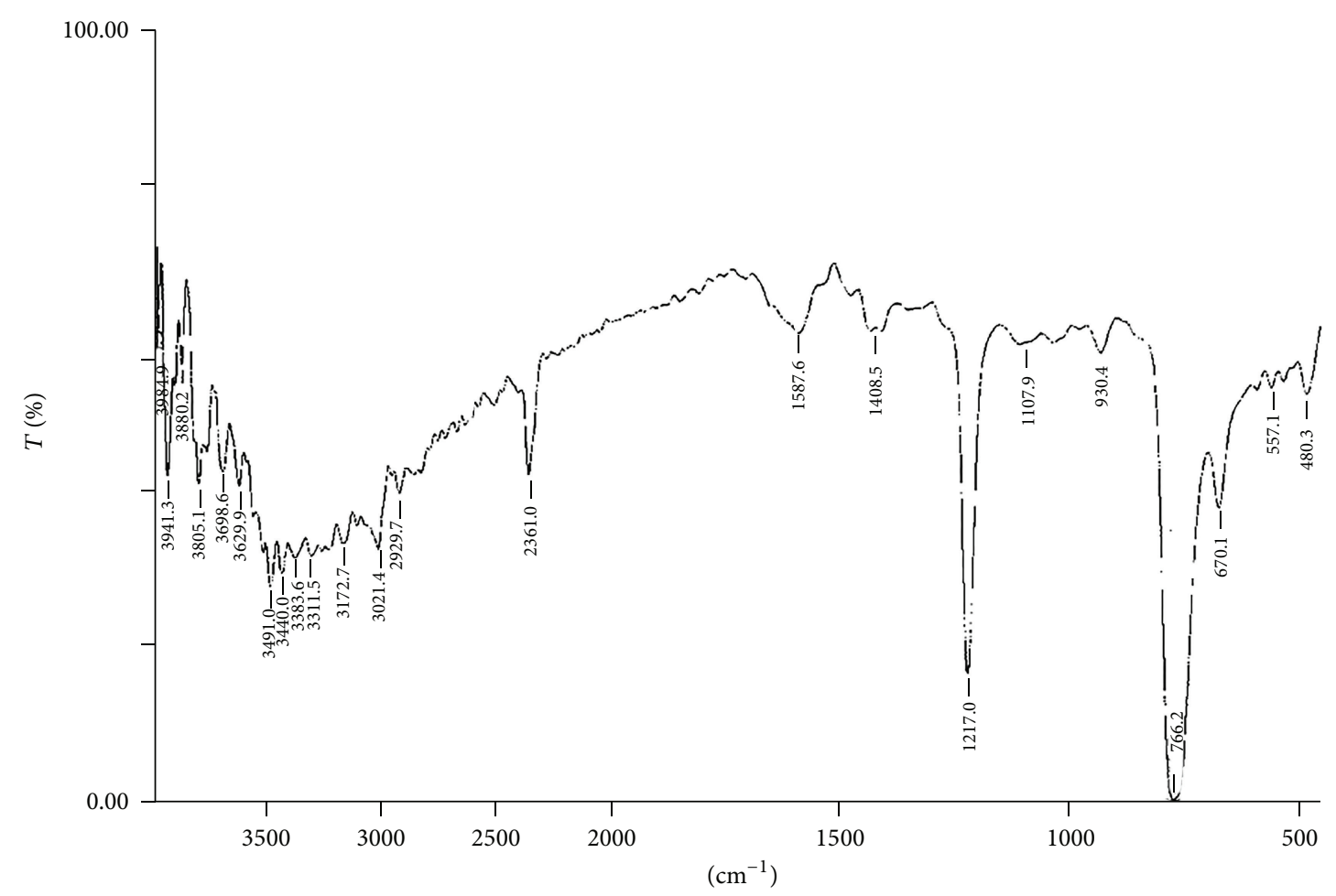

FIGURE 3: IR spectra of metformin-chromium complex.

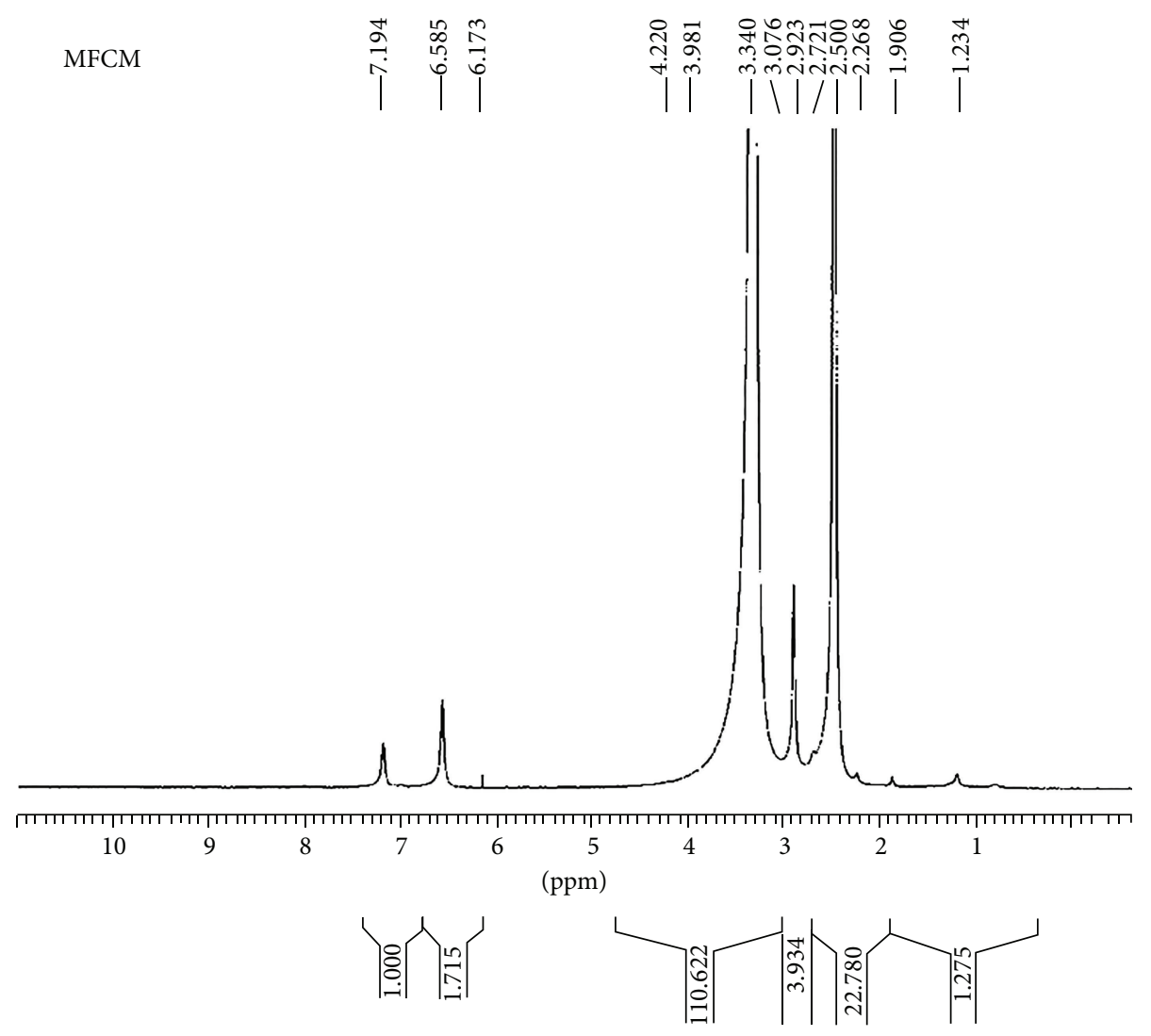

FIGURE 4: NMR spectra of "metformin"-chromium complex. 


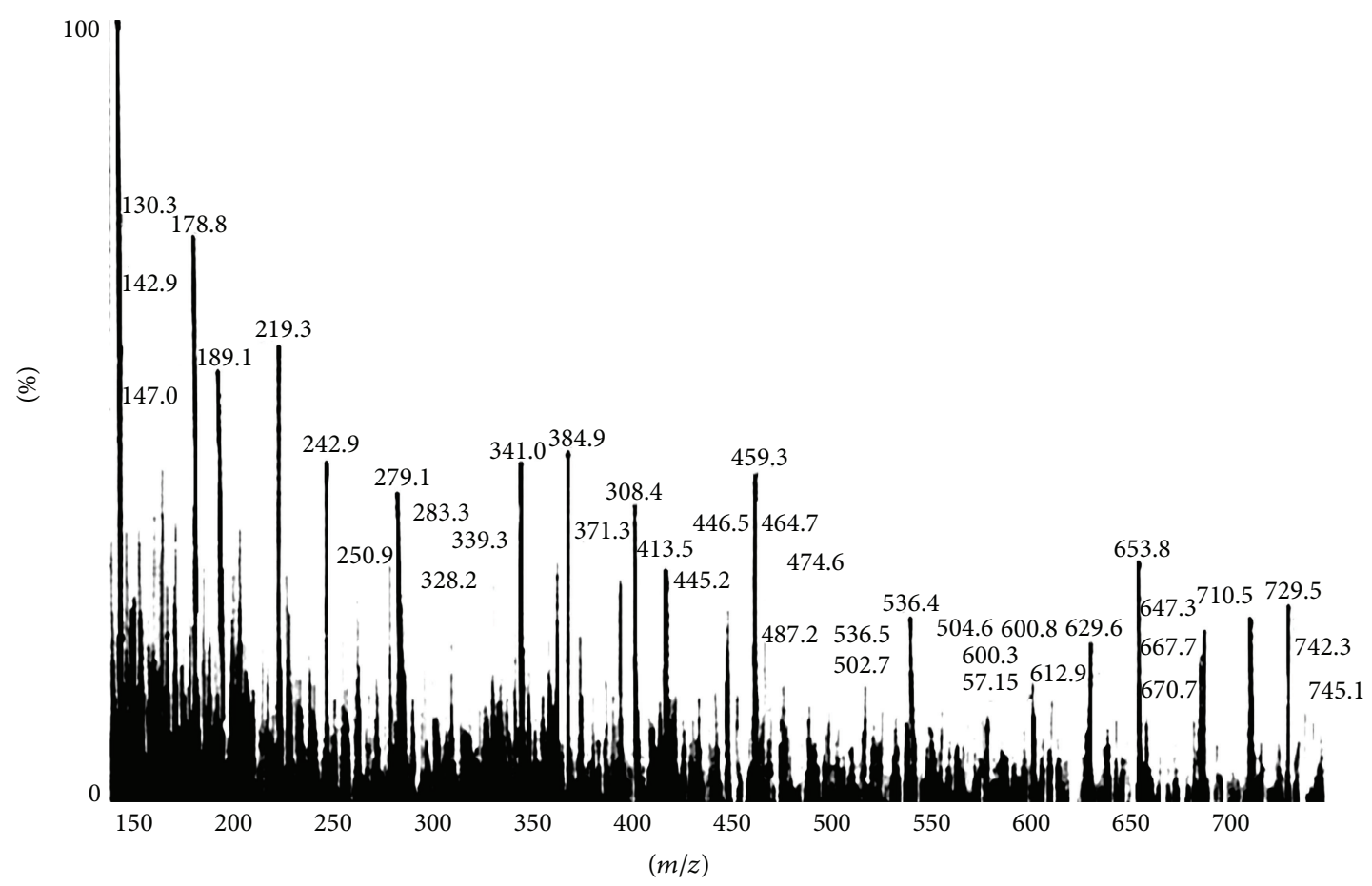

FIgURE 5: Mass spectra of "metformin"-chromium complex.

Similar to amino acid) $3020 \pm 10 \mathrm{~cm}^{-1}, \nu(\mathrm{N}-\mathrm{H}) 3275 \pm$ $20 \mathrm{~cm}^{-1}, \nu(\mathrm{N}-\mathrm{H}) 3520 \pm 20 \mathrm{~cm}^{-1}$, and $\nu$ (coordinate water molecule) $3610 \pm 10 \mathrm{~cm}^{-1}$. The proposed structure for the isolated complex is also supported IR absorptions by [11, 12] Nakamotto [13], Rao [14], Bellamy [15], and Weissberger [16].

3.5. ${ }^{1} H-N M R$ Studies. By ${ }^{1} \mathrm{H}-\mathrm{NMR}$ spectral data it was observed a signal of imide $(\mathrm{NH})$ proton around $(\delta 6.93)$ in the spectrum of the ligand and found less broad band in complex (Figure 4). This also confirms the deprotonation of imide - NH group through enolization (the appearance of $>\mathrm{C}=\mathrm{N}$ stretching band observed in IR spectra). Assignment of "Metformin"-chromium complex, molecular formula $\left[\left(\mathrm{C}_{4} \mathrm{H}_{10} \mathrm{~N}_{5}\right)_{2} \cdot \mathrm{Cr}\left(\mathrm{OH}_{2}\right)_{2}\right] 2 \mathrm{Cl}$ (molecular weight = 414.90), $\delta 7.19$ (s, due to amine salt), $\delta 6.58(\mathrm{~s}, 2 \mathrm{H}, 1 \mathrm{C}=\mathrm{NH}$, $\left.1 \mathrm{C}-\mathrm{NH}-\mathrm{C}, J=2.014 \mathrm{H}_{\mathrm{z}}\right), \delta 2.50\left(\mathrm{~s}, 6 \mathrm{H}, 2\right.$ methyl- $\left.\mathrm{CH}_{3}\right)$ and $\delta 3.34(\mathrm{~s})$, and $\delta 2.92(\mathrm{~s})$, may be due residual solvent $\mathrm{d}_{6}$-DMSO and water of solvent, respectively. The proposed structure for the isolated complex is also supported by Slichter [17], Akit [18], and others [19].

3.6. Mass Spectral Studies. Mass spectrum (Figure 5) of the compound is a plot which represents the intensities of the signals at various $m / z$ values. It is highly characteristic of the compound that no two compounds can have similar mass spectra. It provides information regarding the molecular structure of organic and inorganic compounds [20]. We have found various fragmentation peaks but in the present paper focused only on molecular ion peak of the "Metformin" complex of chromium and assignments are molecular formula of "Metformin"-chromium complex

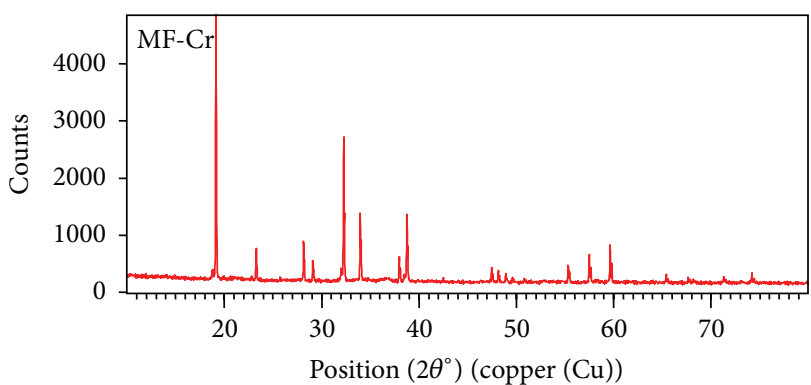

FIgURE 6: X-ray diffractogram of metformin-chromium Complex.

$\left[\left(\mathrm{C}_{4} \mathrm{H}_{10} \mathrm{~N}_{5}\right)_{2} \cdot \mathrm{Cr}\left(\mathrm{OH}_{2}\right)_{2}\right] 2 \mathrm{Cl},(\mathrm{Mol} . \mathrm{Wt} .=414.90), \mathrm{m} / z 413$ due to $\left[\left(\mathrm{C}_{4} \mathrm{H}_{11} \mathrm{~N}_{5}\right)_{2} \mathrm{Cr} \cdot\left(\mathrm{OH}_{2}\right)_{2} \mathrm{Cl}_{2}\right]^{+\bullet}$ or $\left(\mathrm{ML}_{2} \cdot 2 \mathrm{H}_{2} \mathrm{O} \cdot \mathrm{Cl}_{2}\right)^{+\bullet}$ molecular ion peak $\left(\mathrm{m}^{+\bullet}\right) ; \mathrm{m} / z 130$ due to $\left[\left(\mathrm{C}_{4} \mathrm{H}_{11} \mathrm{~N}_{5}\right)\right]^{+\bullet}$ base peak ion $100 \%$ relative abundance.

3.7. X-Ray Diffraction Studies. X-ray diffraction studies also support the complex and formation of new bonds [21-25]. The number of peaks in "metformin" is 13 while that of "Metformin"-chromium complex is 14 as shown in X-ray diffractogram (Figure 6), respectively, indicating that complex formed is a well-knit one; moreover all the reflections are new ones and the patterns are fairly strong. The X-ray pattern have been indexed by using computer software (FPSUIT $2.0 \mathrm{~V}$ ) and applying interactive trial and error method keeping in mind the characteristics of the various symmetry system, till a good fit was obtained between the observed and the calculated $\sin ^{2} \theta$ value. The unit cell parameters were calculated (Table 2) from the indexed data and from 
TABLE 2: Cell data and crystal parameter of metformin-chromium complex.

\begin{tabular}{lcccccc}
\hline $2 \theta$ & $I / I_{0}$ & $D_{(\mathrm{Obs})}$ & $D_{(\mathrm{Cal})}$ & $h$ & $k$ & $l$ \\
\hline 18.7804 & 3.00 & 4.72122 & 4.71104 & 4 & 0 & 3 \\
19.1426 & 100 & 4.63269 & 4.62711 & -4 & 2 & 2 \\
23.2686 & 11.79 & 3.81972 & 3.81881 & -4 & 4 & 2 \\
28.1391 & 14.73 & 3.16886 & 3.16831 & 4 & 5 & 4 \\
31.9838 & 4.73 & 2.79599 & 2.79668 & 5 & 4 & 6 \\
32.2712 & 53.16 & 2.77174 & 2.77213 & 2 & 8 & 2 \\
33.9678 & 25.09 & 2.63708 & 2.63780 & -6 & 5 & 4 \\
38.7600 & 25.61 & 2.32135 & 2.32128 & 1 & 10 & 1 \\
48.1479 & 4.25 & 1.88838 & 1.88835 & -11 & 1 & 4 \\
55.3257 & 6.35 & 1.65917 & 1.65902 & 12 & 4 & 5 \\
57.4998 & 10.57 & 1.60150 & 1.60151 & -6 & 13 & 2 \\
59.6301 & 13.98 & 1.54927 & 1.54928 & 8 & 4 & 14 \\
67.6508 & 2.18 & 1.38378 & 1.38375 & -5 & 13 & 11 \\
74.2048 & 3.86 & 1.27693 & 1.26237 & 14 & 0 & 13 \\
\hline
\end{tabular}

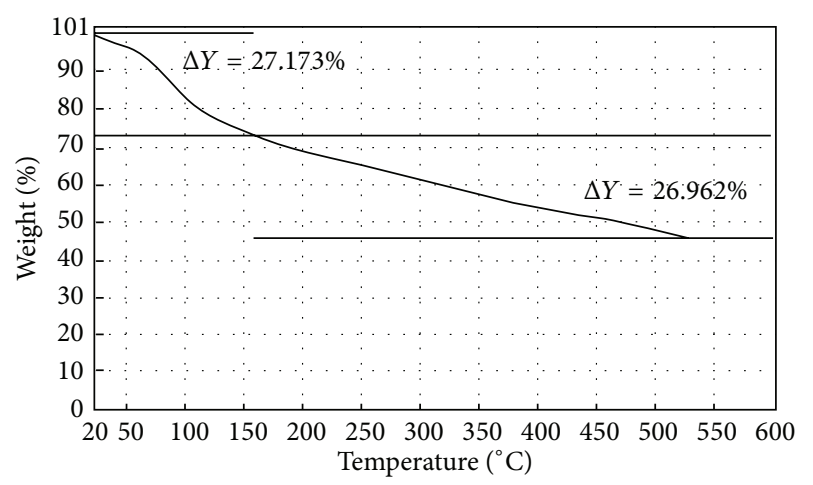

(1) Heat from $30.00^{\circ} \mathrm{C}$ to $630.00^{\circ} \mathrm{C}$ at $20.00^{\circ} \mathrm{C} / \mathrm{min}$

FIGURE 7: TGA curve of metformin-chromium complex.

cell data and crystal lattice parameters of $\mathrm{Cr}$ (III) indicate complex attributed to monoclinic crystal system. Powder Xray diffraction patterns indicate that the synthesized complex are of monoclinic structure. The particle size is 8.301 microns which is calculated from X-ray line broadening using the Scherrer formula $D h k l=\kappa \lambda / \beta h k l \cos \theta$, where $D$ is the particle diameter in ångstroms, $\kappa$ is a coefficient and is equal to 0.89 here, $\beta$ is the half-maximum line width, and $\lambda$ is the wavelength of X-rays and porosity is 0.0207 calculated by formula $\left(d_{\text {true }}-d_{\text {obs }} \times 100\right) / d_{\text {true }}$ and volume of the unit cell is 13748 calculated by Volume $(a b c \sin \beta) \AA$ where $a, b$, and $c$ are lattice parameters. Density $=$ Weight $/$ Volume is found as $0.03007 \mathrm{~g} / \mathrm{cm}^{3}$ for "metformin"-chromium complex. Space group is Pmmm and $\alpha=90^{\circ}, \beta=89.2^{\circ}$, and $\gamma=90^{\circ}$.

3.8. Thermal Study of Metformin-Chromium Complex. In the present investigation, the weight loss for complex was calculated within corresponding temperature ranges of 20$600^{\circ} \mathrm{C}$. The complex is thermally decomposed in two decomposition steps within the temperature range of $50-600^{\circ} \mathrm{C}$. The TGA/DTA curves for the complex are shown in Figure 7.
The thermoanalytical data of Freeman-Carroll and Sharp-Wentworth method are presented in Tables 4 and 5 . In studying the decomposition kinetics methods mentioned in the literature were used in each case in which the least square plots were drawn. The first few points that did not fall on straight line were discarded. These types of deviations of points are reported in literature by several research workers [26]. This is explained as due to the failure of obeying as first order kinetics always by the solids in their decomposition in the early stages.

3.9. Theoretical Consideration. To provide further evidence regarding the degradation system of analyzed compounds we derived the TG curves by applying an analytical method proposed by Freeman-Carroll [27] and Sharp-Wentworth [28].

3.10. Freeman-Carroll Method [27]. The straight line equation derived by Freeman and Carroll is in the form of

$$
\frac{\Delta \log (d w / d t)}{\Delta \log W_{r}}=n-\frac{E_{a}}{2.303 R} \cdot \frac{\Delta(1 / T)}{\Delta \log W_{r}},
$$

where $d w / d t=$ rate of change of weight with time, $W_{r}=W_{c}-$ $W, W_{c}=$ Wt. loss at completion of reaction, $W=$ Total wt. loss up to time " $t$ ", $E_{a}=$ Energy of activation, and $n=$ Order of reaction.

The plot between the term $\Delta \log (d w / d t) / \Delta \log W_{r}$ versus $\Delta(1 / T) / \Delta \log W_{r}$ gives a straight line (Figure 8$)$ from which slope can be calculated; also we obtained energy of activation $\left(E_{a}\right)$ and intercept on $Y$-axis as order of reaction $(n)$ and the change in entropy $(\Delta S)$ also.

3.11. Sharp-Wentworth Method [28]. Using the equation derived by Sharp and Wentworth,

$$
\frac{\Delta \log (d c / d T)}{(1-c)}=\log \frac{A}{B}-\frac{E_{q}}{2.303 R} \cdot \frac{1}{T},
$$

where $d c / d T=$ Rate of change of fraction of weight with change in temperature and $\beta=$ Linear heating rate $d T / d t$, by plotting the graph between $\Delta \log (d c / d T) /(1-c)$ versus $1 / T$.

We obtained the straight line (Figure 9) which gives energy of activation $\left(E_{a}\right)$, from its slope.

Table 3 is given for thermodynamic parameters of complexes, namely, activation energy $\left(E_{a}\right)$. Entropy $(\Delta S)$ and Gibb's free energy change of decomposition $\left(\Delta G^{\circ}\right)$ are evaluated graphically by employing Freeman-Carroll and SharpWentworth relation. The activation energies of decomposition are found to be in the range from 40 to $46 \mathrm{~kJ} \mathrm{Mol}^{-1}$. The high value of activation energies reflects the thermal stability of complex. The entropy of activation is found to have negative values in complex which indicate that decomposition reactions process with lower rate than the normal ones $[26,29-33]$. In TGA curve (Figure 7) the initial loss (8.30\%) (also given in Tables 4 and 5) is due to two molecules of water of crystallization $\left(70-90^{\circ} \mathrm{C}\right)$ in complex which is in agreement with theoretically calculated percentage of water molecule, that is, $8.70 \%$. The $52 \%$ loss at temperature range $100-550^{\circ} \mathrm{C}$ 
TABLE 3: Thermogravimetric data of metformin complex with corresponding to heating rate of $10^{\circ} \mathrm{C} / \mathrm{min}$.

\begin{tabular}{|c|c|c|c|c|c|c|c|}
\hline \multirow{2}{*}{ Complex } & \multirow{2}{*}{ Decomposition temp. $\left({ }^{\circ} \mathrm{C}\right)$} & \multirow{2}{*}{$\% \mathrm{Wt}$. loss } & \multicolumn{2}{|c|}{$\mathrm{Ea}(\mathrm{Kj} / \mathrm{mole})$} & \multirow{2}{*}{$\Delta S^{*}(\mathrm{Kj} / \mathrm{mole})$} & \multirow{2}{*}{$\Delta F(\mathrm{Kj} / \mathrm{mole})$} & \multirow{2}{*}{$n$} \\
\hline & & & S.W. & F.C. & & & \\
\hline$\left[\left(\mathrm{C}_{5} \mathrm{H}_{11} \mathrm{~N}_{5}\right)_{2} \mathrm{Cr} \cdot\left(\mathrm{OH}_{2}\right)_{2}\right] 2 \mathrm{Cl}$ & $40-600$ & 60 & 46.21 & 45.33 & -73.97 & -22.57 & 0.83 \\
\hline
\end{tabular}

S.W.: Sharp-Wentworth method; F.C.: Freeman-Carroll method.

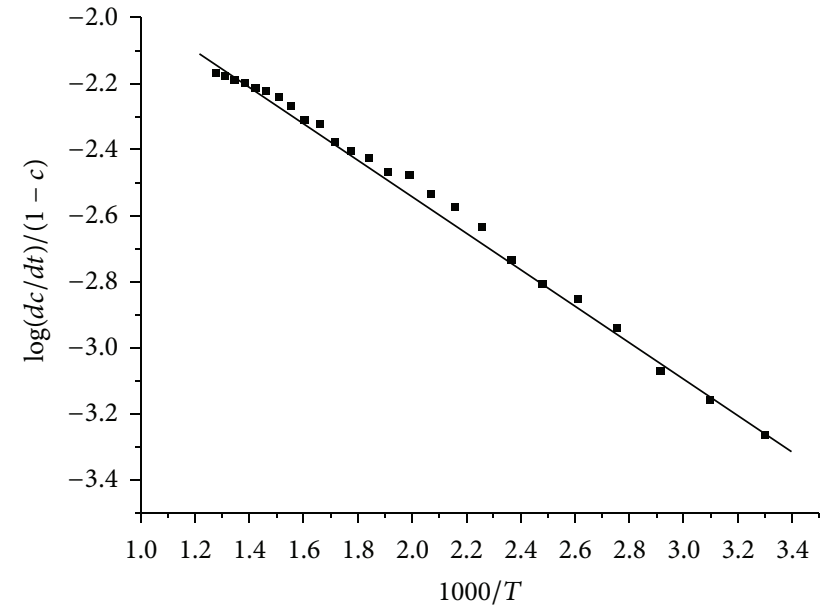

FIGURE 8: Sharp-Wentworth kinetic plot of metformin-chromium complex using TGA data.

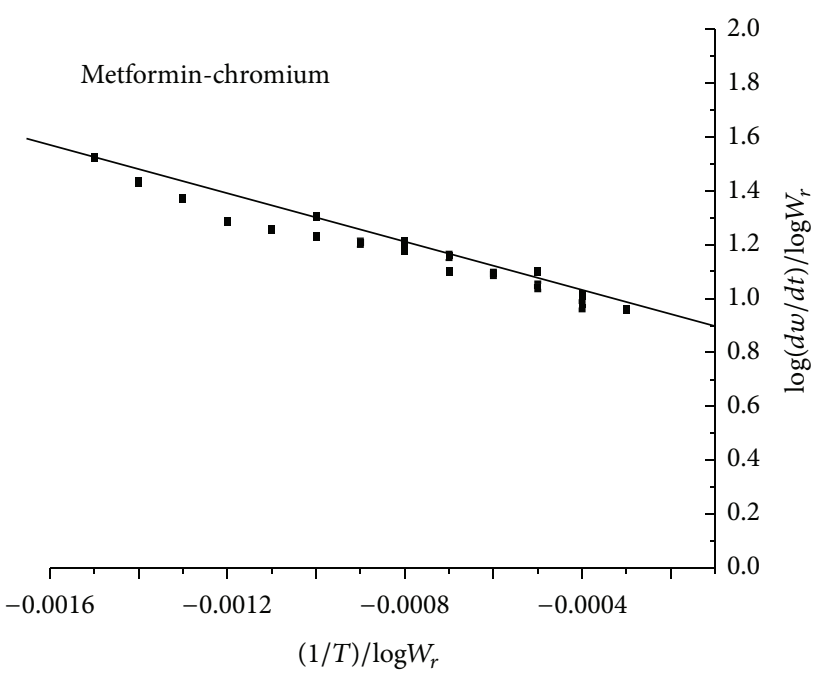

FIGURE 9: Freeman and Carroll kinetic plot of metforminchromium complex using TGA data.

is due to loss of organic moiety and above $550^{\circ} \mathrm{C}$ there is no loss (45\%) which is due the formation metal oxide.

\section{Discussion}

For supporting the proposed structure of chromium complex with "metformin" initially monovariation method was conducted which indicates $1: 2$ metal: ligand ratio which was further confirmed by Job's method of continuous variation<smiles>CN1C(=N)NC(N)=NC1(O)N1C(=N)NC([NH3+])=NC1(C)C</smiles>

Scheme 2: Proposed Structure-I for metformin-chromium complex.

as modified by Turner and Anderson (Scheme 2). Moreover stability constant and free energy change were also calculated from modified Job's method. From stoichiometry and analytical data, the composition of the complex comes out to be $\left[\left(\mathrm{C}_{4} \mathrm{H}_{10} \mathrm{~N}_{5}\right)_{2} \mathrm{Cr}\left(\mathrm{OH}_{2}\right)_{2}\right] 2 \mathrm{Cl}$, which favors $2: 1\left(\mathrm{~L}_{2} \mathrm{M}\right)$ ratio. The proposed structure (I) for chromium complex of "metformin" was further supported by spectroscopic methods like IR, ${ }^{1} \mathrm{H}-\mathrm{NMR}$, electronic spectra and mass spectral studies, and so forth. The biguanidine unit inside the coordination sphere has a positive charge while $\mathrm{Cl}^{-}$occupies the outer place of the coordination sphere. The IR spectral assignments show the $\mathrm{M}-\mathrm{N}$ frequency and confirm the linkage of $\mathrm{N}^{4}$ to the metal through the covalent bond. Moreover, the difference in the NMR peak of the drug (wide peak) and the complex (narrow peak) are further supporting the removal of one of the " $\mathrm{H}$ " from the $\mathrm{N}-\mathrm{H}$ group through enolisation. Mass spectral results further support the formation of complex which observed a molecular ion peak. A detailed study of X-ray also supports the complex formation and the various parameters like particle size, porosity, volume of unit cell, density, and crystal system were evaluated and discussed. Thermal analysis has been studied by giving their relative thermal stability, applying the Sharp-Wentworth and Freeman-Carroll methods: energy of activation $\left(E_{a}\right)$ and kinetic parameter, namely, $\Delta S, \Delta F$, and order of reaction $(n)$ were determined by applying Freeman-Carroll method. TGA curve gives strong support of presence of coordinate water molecule.

\section{Conclusion}

In the present paper we have syntheses complex of antidiabetic drug with chromium and have given its spectral characterization and kinetics parameters, which gives the 


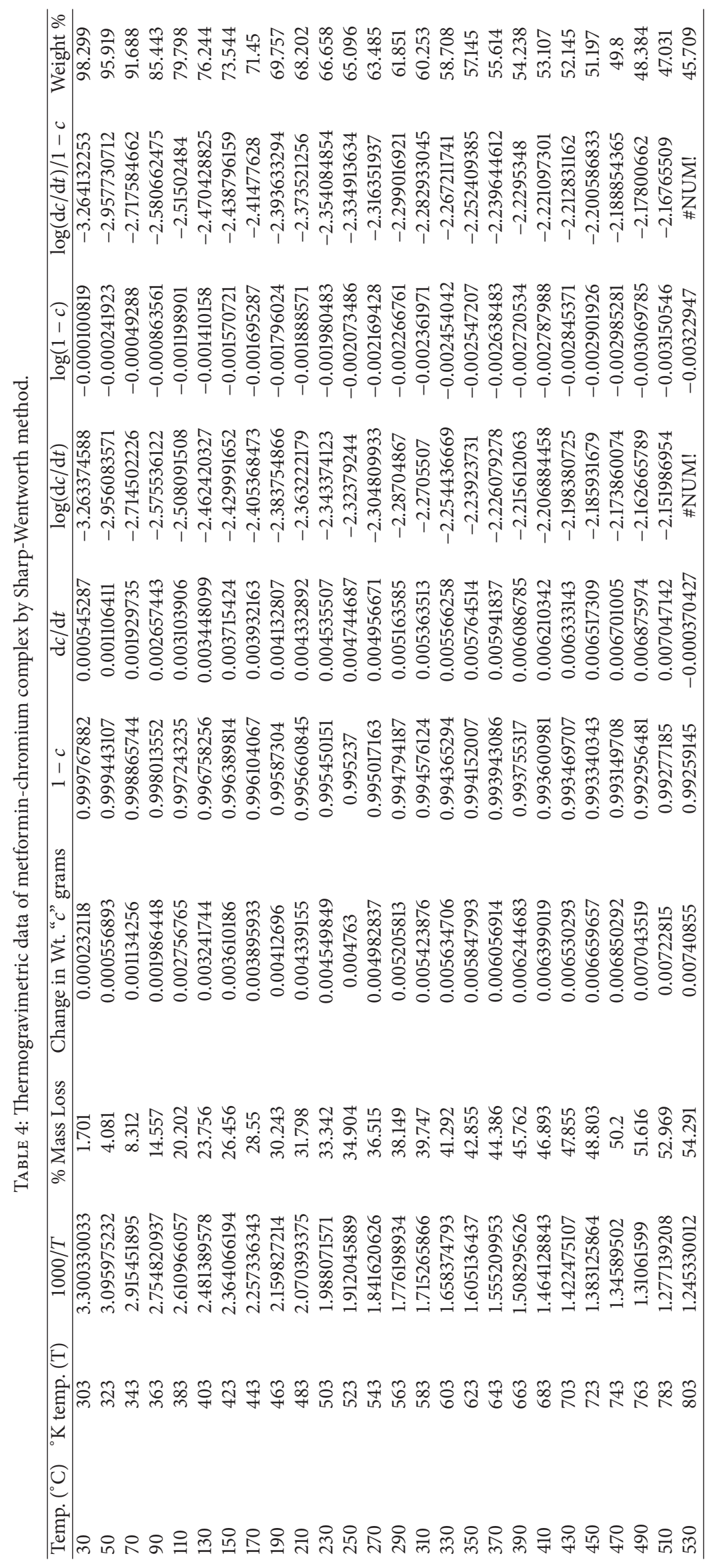




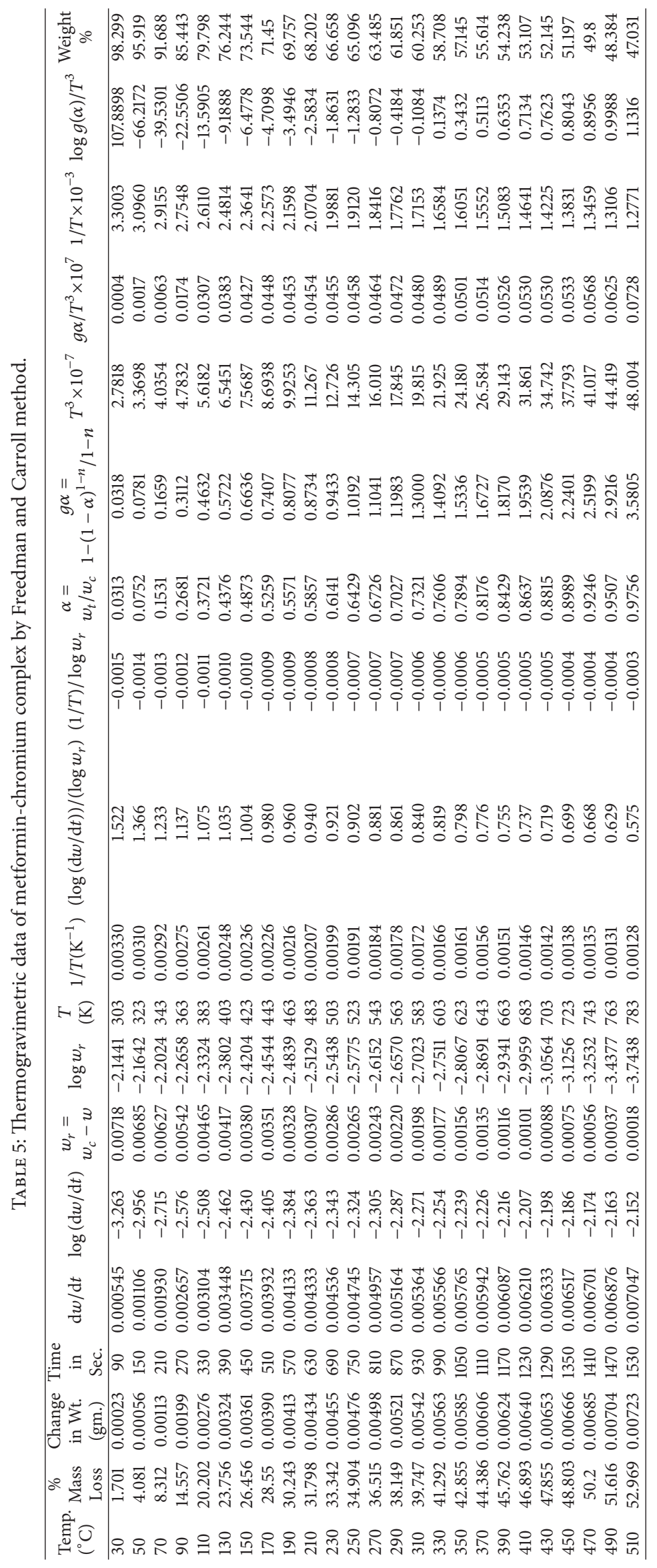


detailed information of the new structure for coordination chemistry. Moreover in our previous work we have carried out comparative study for hypoglycemic activity of parent drug and its complexes with various transition metals and found that the complexes are more potent than pure drug. By doing some clinical action it can be used for men and it will be a new drug for diabetes patients.

\section{Conflict of Interests}

The authors declare that there is no conflict of interests regarding the publication of this paper.

\section{Acknowledgments}

The author is thankful to the principal of Saifia Science College, Bhopal, and Principal of Crescent College of Technology, Bhopal, for providing all necessary facilities. The author is also thankful to I.I.T and C.D.R.I, Lucknow for providing IR and NMR spectra, C.D.R.I and analytical data.

\section{References}

[1] E. J. Underwood, Trace Element in Human and Animal Nutrition, Academic Press, New York, NY, USA, 3rd edition, 1971.

[2] S. M. Sadilot and R. B. Pathak, Journal ofDiabetes Association, vol. 32, no. 4, 1992.

[3] Z. N. Bloomgarden, "American Diabetes Association Consensus Statement on pharmacologic treatment," Diabetes Care, vol. 22, pp. S1-S114, 1999.

[4] F. Sanger and E. O. L. Thompson, The Biochemical Journal, vol. 53, pp. 366-535, 1951.

[5] I. Yoshinaga and Y. Yamamotto, Endocrinologie, vol. 50, no. 3, 1966.

[6] I. Yoshinaga and Y. Yamamotto, J.Osaka., vol. 1, no. 3, 1966.

[7] S. A. Iqbal, S. Jose, and I. Zaafarany, "Synthesis, physicochemical and spectral studies of mercury complex of glibenclamide: an oral antidiabetic drug," Oriental Journal of Chemistry, vol. 28, no. 1, pp. 613-618, 2012.

[8] D. Veer and M. Baboo, "Synthesis and spectral studies of some transition metal complexes," Oriental Journal of Chemistry, vol. 28, no. 4, pp. 1797-1802, 2012.

[9] P. Job, "Formation and stability of inorganic com-plexes in solution," Annales de Chimie, vol. 10, p. 113, 1928.

[10] S. E. Turner and R. C. Anderson, "Spectrophotometric studies on complex formation with sulfosalicylic acid. III. with Copper(II)," Journal of the American Chemical Society, vol. 71, no. 3, pp. 912-914, 1949.

[11] B. Krishan and O. Prakash, "Synthesis characterization and spectral studies of gold complex with gliclazide," Oriental Journal of Chemistry, vol. 29, no. 1, pp. 381-388, 2013.

[12] G. Valarmathy, R. Subbalakshmi, R. Selvameena, and V. Gomathi, "Synthesis and characterization and antimicrobial screening of $\mathrm{Co}(\mathrm{II}), \mathrm{Mn}(\mathrm{II}), \mathrm{Ni}(\mathrm{II}), \mathrm{Cu}(\mathrm{II})$ and $\mathrm{Zn}$ (II) complexes of Schiff base ligand," Oriental Journal of Chemistry, vol. 29, no. 1, pp. 315-320, 2013.

[13] K. Nakamotto, Infrared Spectra of Inorganic and Coordination Compounds, John Wiley \& Sons, New York, NY, USA, 1963.

[14] C. N. R. Rao, Chemical Applications of Infrared Spectroscopy, Academic Press, New York, NY, USA, 1963.
[15] L. J. Bellamy, The Infrared Spectra of Complex Molecules, Matheun \& Co., London, UK, 1964.

[16] A. Weissberger, Technique of Organic Chemistry: Chemical Applications of Spectroscopy, vol. 11, Wiley-Interscience, New York, NY, USA, 1956.

[17] C. P. Slichter, Principles of Magnetic Resonance: With Examples from Solid State Physics, vol. 7, Harper \& Row, New York, NY, USA, 1963.

[18] J. W. Akit, NMR and Chemistry: An Introduction to Nuclear Magnetic Resonance Spectroscopy, Champan and Hall, London, UK, 1973.

[19] Md. Tawkir, S. A. Iqbal, B. Krishan, and I. Zaafarany, "Synthesis and characterisation of glimeperide complexes of copper, magnesium, nickel and cadmium," Oriental Journal of Chemistry, vol. 27, no. 2, pp. 603-609, 2011.

[20] F. W. McLafferty and F. Turecek, Interpretation of Mass Spectra, University Science Books, Sausalito, Calif, USA, 4th edition, 1993.

[21] B. D. Cullity, Elements of X-Ray Diffraction, Addison-Wesley, Boston, Mass, USA, 2nd edition, 1978.

[22] B. Krishan, M. Tawkir, and S. A. Iqbal, "X-ray diffraction studies of $\mathrm{Co}(\mathrm{II}), \mathrm{Sm}$ (III) and $\mathrm{Nd}(\mathrm{III})$ with gliclazide-an oral antidiabetic drug," Oriental Journal of Chemistry, vol. 28, no. 4, pp. 1883-1888, 2012.

[23] W. L. Bragg and W. H. Bragg, The Crystalline State: A General Survey, George Bell \& Sons, London, UK, 1993.

[24] A. Guiner, X-Ray Crystallographic Technology, Hilger and Watts, London, UK, 1952.

[25] N. F. M. Henry, H. Lipson, and W. A. Wooster, The Interpretation of X-Ray Diffraction Photographs, Macmillan, London, UK, 1951.

[26] R. N. Singru, "Synthesis, characterization and thermal degradation studies of copolymer resin p-cresol-oxamideformaldhyde," Archives of Applied Science Research, vol. 3, no. 5, pp. 309-325, 2011.

[27] E. S. Freeman and B. Carroll, "The application of thermoanalytical techniques to reaction kinetics: the thermogravimetric evaluation of the kinetics of the decomposition of calcium oxalate monohydrate," The Journal of Physical Chemistry, vol. 62, no. 4, pp. 394-397, 1958.

[28] J. H. Sharp and S. A. Wentworth, "Kinetic analysis of thermogravimetric data," Analytical Chemistry, vol. 41, no. 14, pp. 20602062, 1969.

[29] S. S. Rahangdale, W. B. Gurnule, and Synthesis, "Thermal and electrical properties of 2,2-HBBR Copolymer Resin," Chemical Science Transactions, vol. 2, no. 1, pp. 287-293, 2013.

[30] C. Duval, Inorganic Thermogravimetric Analysis, Elsevier, London, UK, 1983.

[31] P. C. S. Rani, G. S. Thara, and R. K. Lekshmy, "Synthesis and characterization of copper complexes of a Schiff base," Oriental Journal of Chemistry, vol. 29, no. 1, pp. 309-313, 2013.

[32] M. Tawkir, K. Khairou, and I. Zaafarany, "Spectroscopic and thermal characterization of gliclazide, glibenclamide and glimpride complexes with transition and inner-transition metals," Oriental Journal of Chemistry, vol. 28, no. 4, pp. 1697-1710, 2012.

[33] B. K. Rai, Ranjana, P. Prakash, and P. Lata, "Synthesis, spectral and biocidal screening of Schiff base complexes of $\mathrm{Co}(\mathrm{II}), \mathrm{Ni}(\mathrm{II})$ and $\mathrm{Cu}(\mathrm{II})$ containing nitrogen and sulpher doner atoms," Oriental Journal of Chemistry, vol. 28, no. 4, pp. 1803-1808, 2012. 

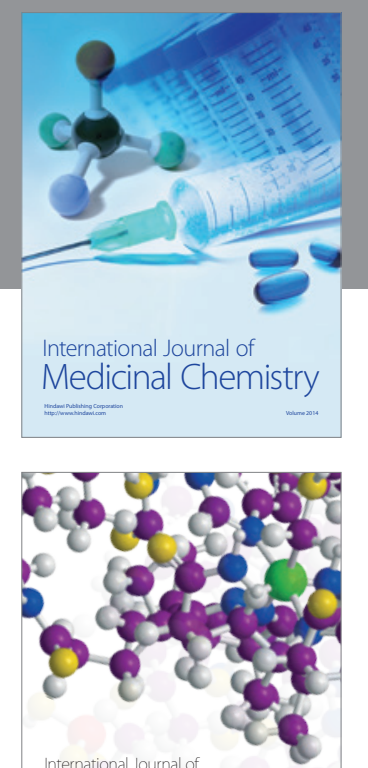

\section{Carbohydrate} Chemistry

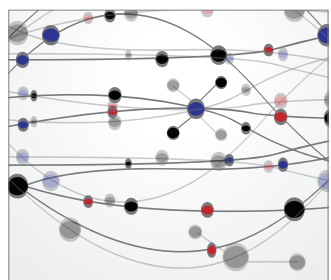

The Scientific World Journal
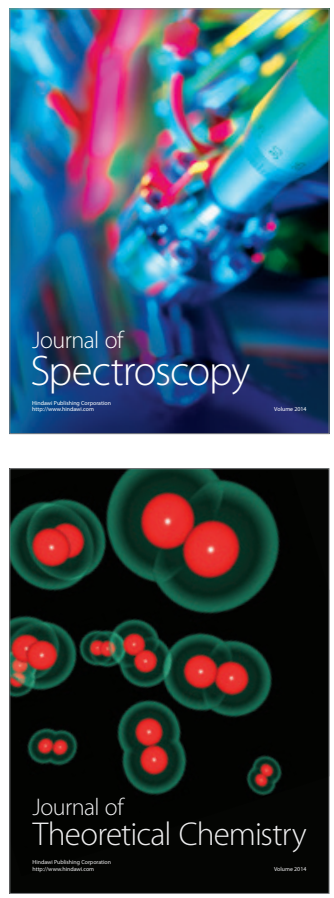
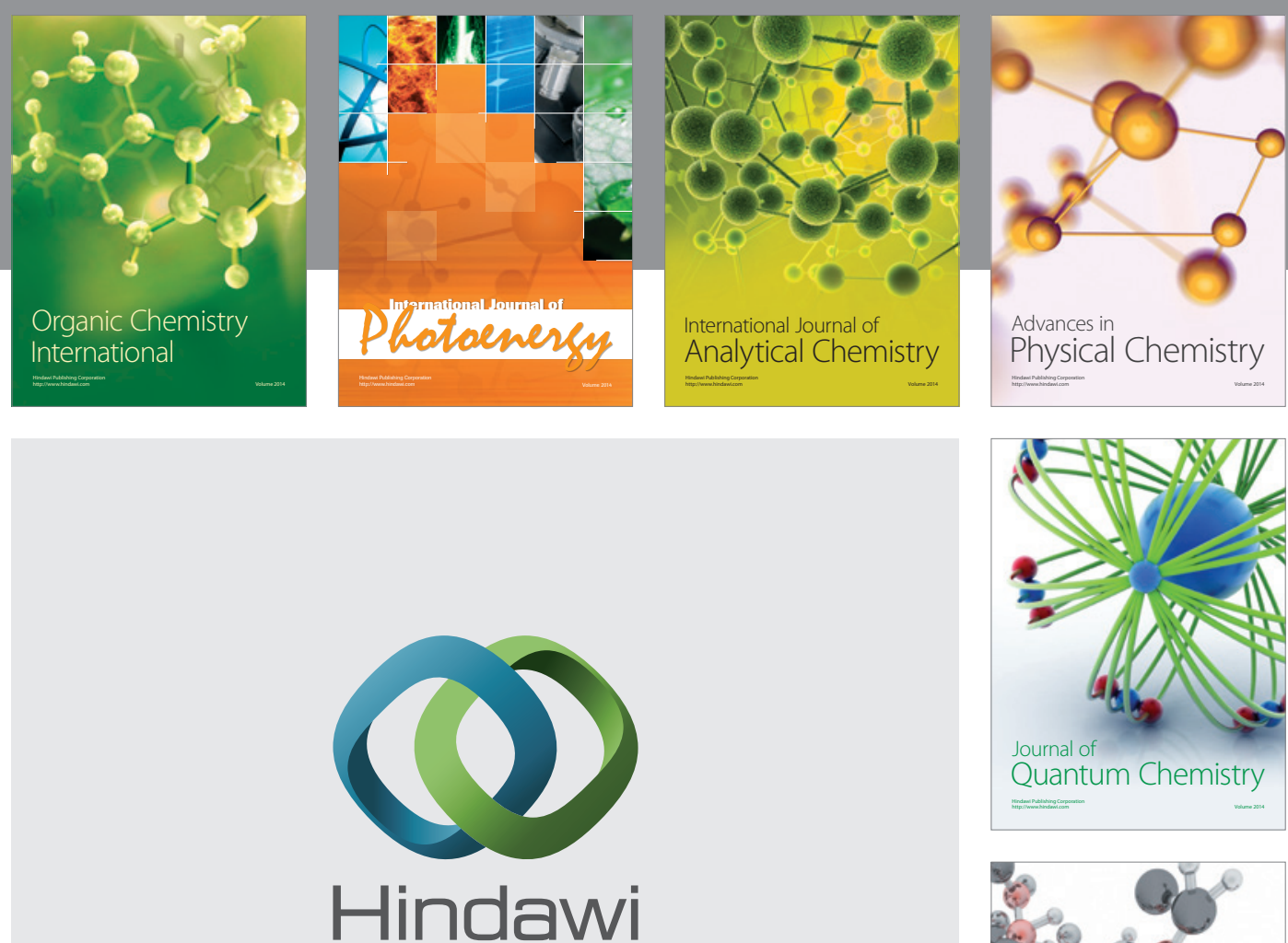

Submit your manuscripts at

http://www.hindawi.com

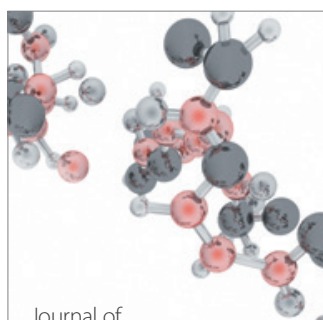

Analytical Methods

in Chemistry

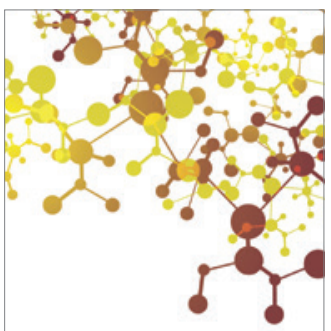

Journal of

Applied Chemistry

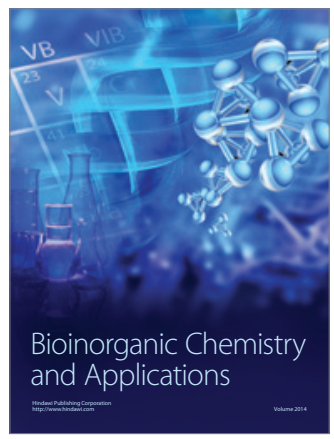

Inorganic Chemistry
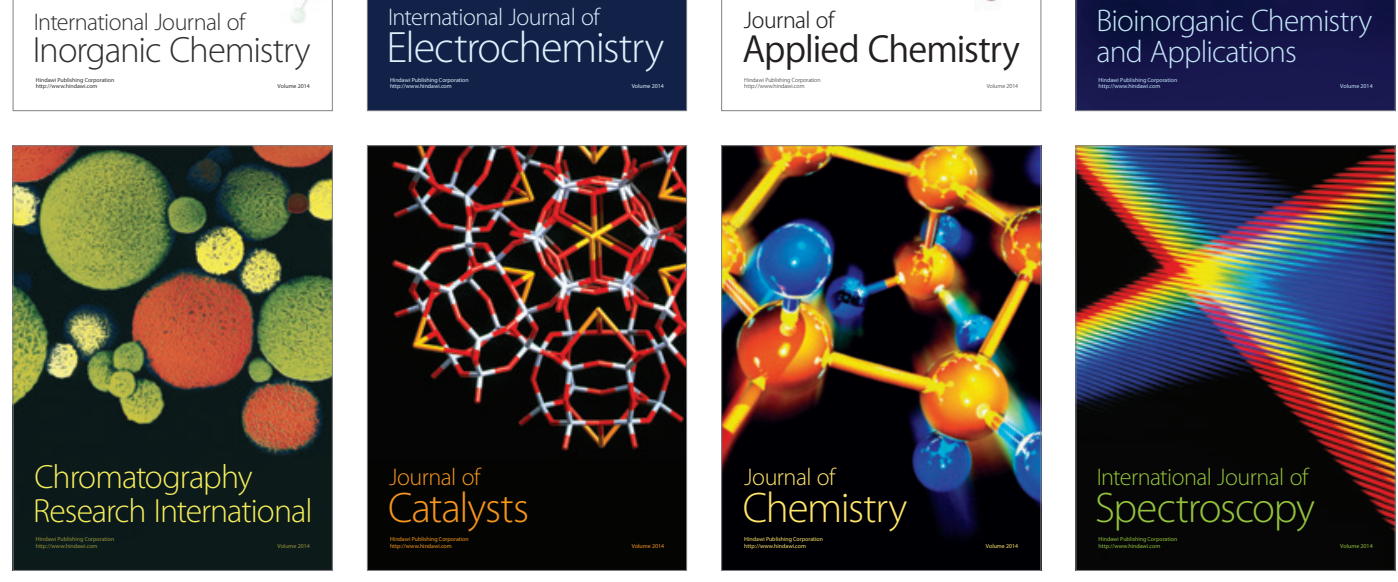